Marquette University

e-Publications@Marquette

$5-2021$

\title{
Five-Year Change in Body Mass Index Predicts Conversion to Mild Cognitive Impairment or Dementia Only in APOE \&4 Allele Carriers
}

Kylie R. Kadey

Wayne State University

John L. Woodard

Wayne State University

Allison C. Moll

Wayne State University

Kristy A. Nielson

Marquette University, kristy.nielson@marquette.edu

J. Carson Smith

University of Maryland at College Park

See next page for additional authors

Follow this and additional works at: https://epublications.marquette.edu/psych_fac

Part of the Psychology Commons

\section{Recommended Citation}

Kadey, Kylie R.; Woodard, John L.; Moll, Allison C.; Nielson, Kristy A.; Smith, J. Carson; Durgerian, Sally; and Rao, Stephen M., "Five-Year Change in Body Mass Index Predicts Conversion to Mild Cognitive Impairment or Dementia Only in APOE \&4 Allele Carriers" (2021). Psychology Faculty Research and Publications. 500. https://epublications.marquette.edu/psych_fac/500 


\section{Authors}

Kylie R. Kadey, John L. Woodard, Allison C. Moll, Kristy A. Nielson, J. Carson Smith, Sally Durgerian, and Stephen M. Rao 
Marquette University

e-Publications@Marquette

\section{Psychology Faculty Research and Publications/College of Arts and Sciences}

This paper is NOT THE PUBLISHED VERSION.

Access the published version via the link in the citation below.

Journal of Alzheimer's Disease, Vol. 81, No. 1 (May 2021): 189-199. DOI. This article is (C) IOS Press and permission has been granted for this version to appear in e-Publications@Marquette. IOS Press does not grant permission for this article to be further copied/distributed or hosted elsewhere without the express permission from IOS Press.

\section{Five-Year Change in Body Mass Index Predicts Conversion to Mild Cognitive Impairment or Dementia Only in APOE \&4 Allele Carriers}

Kylie R. Kadey

Department of Psychology, Wayne State University, Detroit, MI John L. Woodard Department of Psychology, Wayne State University, Detroit, MI, Allison C. Moll

Department of Psychology, Wayne State University, Detroit, MI, Kristy A. Nielson Department of Psychology, Marquette University, Milwaukee, WI Department of Neurology, Medical College of Wisconsin, Milwaukee, WI Carson J. Smith Department of Kinesiology, University of Maryland, College Park, MD Sally Durgerian BrainDataDriven LLC, Shorewood, WI

Stephen M. Rao 
Schey Center for Cognitive Neuroimaging, Neurological Institute, Cleveland Clinic, Cleveland, $\mathrm{OH}$

\section{Abstract}

\section{Background:}

Body mass index (BMI) has been identified as an important modifiable lifestyle risk factor for dementia, but less is known about how BMI might interact with Apolipoprotein E \&4 (APOE \&4) carrier status to predict conversion to mild cognitive impairment (MCl) and dementia.

\section{Objective:}

The aim of this study was to investigate the interaction between APOE \&4 status and baseline ( $\left.{ }_{\mathrm{b}} \mathrm{BMI}\right)$ and fiveyear $\mathrm{BMI}$ change $(\triangle \mathrm{BMI})$ on conversion to $\mathrm{MCl}$ or dementia in initially cognitively healthy older adults.

\section{Methods:}

The associations between ${ }_{\mathrm{b}} \mathrm{BMI}, \triangle \mathrm{BMI}, A P O E \varepsilon 4$ status, and conversion to $\mathrm{MCl}$ or dementia were investigated among 1,289 cognitively healthy elders from the National Alzheimer's Coordinating Center (NACC) database.

\section{Results:}

After five years, significantly more carriers (30.6\%) converted to $\mathrm{MCl}$ or dementia than noncarriers $(17.6 \%), p<0.001, O R=2.06$. Neither ${ }_{b} \mathrm{BMI}(\mathrm{OR}=0.99,95 \% \mathrm{Cl}=0.96-1.02)$ nor the ${ }_{b} \mathrm{BMI}$ by $A P O E$ interaction $(\mathrm{OR}=1.02,95 \% \mathrm{Cl}=0.96-1.08)$ predicted conversion. Although $\triangle \mathrm{BMI}$ also did not significantly predict conversion $(\mathrm{OR}=0.90,95 \% \mathrm{Cl}=0.78-1.04)$, the interaction between $\triangle \mathrm{BMI}$ and carrier status was significant $(\mathrm{OR}=0.72$, $95 \% \mathrm{Cl}=0.53-0.98)$. For carriers only, each one-unit decline in $\mathrm{BMI}$ over five years was associated with a $27 \%$ increase in the odds of conversion $(\mathrm{OR}=0.73,95 \% \mathrm{Cl}=0.57-0.94)$.

\section{Conclusion:}

A decline in $\mathrm{BMI}$ over five years, but not ${ }_{b} \mathrm{BMI}$, was strongly associated with conversion to $\mathrm{MCl}$ or dementia only for $A P O E \& 4$ carriers. Interventions and behaviors aimed at maintaining body mass may be important for long term cognitive health in older adults at genetic risk for AD.

\section{INTRODUCTION}

The Apolipoprotein E \&4 (APOE \&4) allele is an important genetic risk factor for late onset Alzhei-mer's disease (AD). Having one $\varepsilon 4$ allele triples one's risk of developing AD and having two $\varepsilon 4$ alleles is associated with a 12 times greater risk of $A D$ compared to those with no $\varepsilon 4$ allele $[1,2]$. Yet not all carriers develop AD during their lifespan, with nearly 50\%of homozygous APOE $\varepsilon 4$ carriers aged 80 or older never developing AD [3]. Potentially modifiable factors, such as physical activity, may influence whether a cognitively intact carrier develops mild cognitive impairment (MCl) or AD [4-7]. Obesity is another modifiable lifestyle factor, but it is unclear whether body mass is a significant predictor of conversion from cognitively intact to $\mathrm{MCl} / \mathrm{AD}$.

Results of studies examining the relationship between body mass or weight in healthy individuals and the future risk of developing dementia are contradictory. Several studies have shown that increased body mass index (BMI) in midlife raises the risk of developing dementia [8-15]. In a sample of 8,534 twins, being overweight or obese in midlife was associated with an increased risk of dementia, AD, and vascular dementia [14]. In addition, this relationship was attenuated in dementia-discordant twin pairs, indicating that genetic and family environmental factors may contribute to the relationship between high BMI and dementia. Another study found that each unit increase in BMI during midlife predicted an earlier onset of $A D$ by 6.7 months, suggesting that maintaining a healthy BMI in midlife may delay the onset of $A D$ [16]. Paradoxically, other reports suggest that a low BMI 
$\left(<20 \mathrm{~kg} / \mathrm{m}^{2}\right)$ in late-life increases the risk of $\mathrm{MCl}$ or dementia, whereas high $\mathrm{BMI}\left(>30 \mathrm{~kg} / \mathrm{m}^{2}\right)$ reduces the risk [10, 17-19]. In a sample of 6,940 older adults from the National Alzheimer's Coordinating Center Uniform Data Set, higher late-life baseline BMI was associated with a reduced risk of conversion to $\mathrm{MCl}$ over a mean 3.8-year period $(\mathrm{OR}=0.977)$, but higher $\mathrm{BMI}$ was no longer protective when rapid weight loss was present [20]. Other studies have shown that a decline in BMI during mid-life increases the risk of AD in late-life [9, 21-27]. Finally, others have shown that both weight gain and weight loss are associated with incidence of dementia [28]. Overall, these results demonstrate that the relationship between BMI and dementia risk is complicated and dependent on age, with higher BMI increasing risk of dementia in midlife while being apparently protective in late life [29]. Maintaining a stable BMI throughout midlife and late life appears to be associated with a reduced risk of dementia.

Whereas a number of studies have examined the relationship between $\mathrm{BMI}$ and risk of conversion to dementia, there has been little examination into the role of $A P O E$ genotype as a potential moderator variable. One pilot study analyzed a sample of 153 older adults with late-onset Alzheimer's disease (LOAD; mean age 78.2 years) and 302 control subjects (mean age 87.2 years) to determine various gene/gene and gene/environment relationships that predict $A D$ [30]. They found that APOE \&4 carriers (but not noncarriers) with LOAD were more likely to have been obese at age 50. Other studies have shown that lower BMI in old age is associated with poorer cognition in APOE \&4 carriers only. In a longitudinal study that followed older adults aged 65 and older for over 10 years, $\mathrm{BMI}$ and $A P O E \varepsilon 4$ carrier status interacted to predict cognitive impairment, with lower $\mathrm{BMI}$ predicting greater cognitive impairment for carriers only [31]. Another study reported that in elder APOE ع4 carriers only, a lower BMI was associated with greater cognitive decline, whereas obesity was associated with improved cognitive performance and slower progression of cognitive decline [32]. Conversely, other studies have found no $A P O E \& 4 \times \mathrm{BMI}$ interaction on dementia risk [11,33]. In a sample of 1,890 Japanese American men followed longitudinally for 32 years, those who developed dementia had greater weight loss in the six years prior to diagnosis than those who did not develop dementia [34]. The APOE $\varepsilon 4$ allele did not modify this relationship, but there was a trend toward the rate of weight change being weaker in AD patients who were $A P O E \varepsilon 4$ carriers. Therefore, the literature on this topic is still inconclusive, with some studies revealing that the relationship between measures of adiposity and cognitive decline in old age is stronger in APOE $\varepsilon 4$ carriers than in noncarriers and others suggesting no relationship at all. To our knowledge, no study has examined how $A P O E \varepsilon 4$ carrier status and change in $\mathrm{BMI}$ interact to predict conversion to $\mathrm{MCl}$ or dementia in a sample of cognitively healthy elders.

$A P O E \varepsilon 4$ is a risk factor for cardiovascular and metabolic disease, and results in poor handling of cholesterol and compromised glucose metabolism, in addition to being associated with a reduced capacity to clear brain amyloid $[35,36]$. Thus, it is reasonable to hypothesize that $A P O E$ genotype and other metabolic processes that lead to increased body mass may interact and exacerbate cognitive decline. The purpose of the current study was to further examine the relationship between $\mathrm{BMI}$ and conversion to dementia by examining the possible moderating roles of the APOE \&4 allele using data from the National Alzheimer's Coordinating Center (NACC) Uniform Data Set (UDS). Specifically, we examined whether baseline BMI in healthy elders predicts conversion to $\mathrm{MCl}$ over a five-year follow-up interval differentially in APOE carriers and noncarriers. We also examined whether changes in BMI over the five-year interval were associated with conversion and carrier status.

\section{METHODS}

\section{Setting and participants}

This report is based on analyses from 36 Alzhei-mer's Disease Research Centers (ADRCs) for UDS visits conducted between September 2005 and March 2019. For a complete description of data and procedures, refer to Beekly et al. (2007) and Besser et al. $(2018)[37,38]$. The sample was restricted to 1,289 individuals who were 
specifically recruited to be cognitively intact at initial visit (see Fig. 1 for selection and exclusion details). Participants included 386 heterozygous APOE $\varepsilon 4$ carriers $(\varepsilon 3 / \varepsilon 4)$ and 903 noncarriers $(\varepsilon 3 / \varepsilon 3)$ who were 65 to 80 years of age at baseline $(M=72.1, S D=4.5)$ with a valid $B M I$ assessed at baseline and five-year follow-up within the range of 10 to $100(M=27.1, S D=5.1)$. Homozygous carriers $(\varepsilon 4 / \varepsilon 4 ; N=44)$ and those containing the protective $\varepsilon 2$ allele $(N=234)$ were excluded from analyses. There were 1,085 (84.2\%) white and $204(15.8 \%)$ nonwhite individuals in the overall sample. The sample included participants who either remained cognitively normal or proceeded to develop $\mathrm{MCl}$ or $\mathrm{AD}$ (primary, contributing, or non-contributing) within 4.8 to 5.7 years $(M=5.2, S D=0.2)$, representing the 25th to 75th percentiles of all follow-ups approximating five years. Individuals who reverted at any visit from $\mathrm{MCl}$ to cognitively normal or from $\mathrm{AD}$ to either $\mathrm{MCl}$ or cognitively normal were excluded from analyses. Furthermore, 17 participants were removed from all analyses as outliers on at least two of the following three criteria, as measured by influence plots: hat-values, Cook's distance, and studentized residuals. All participants performed within age- and sex-appropriate limits at initial visit. All participants provided written informed consent and were financially compensated for participation. Because of missing data on various measures, the sample size for specific analyses varied slightly from the maximum of 1,289 (see Table 1).

Fig. 1. Consort Diagram Displaying Derivation of Study Sample for Analysis with Source of Exclusion.

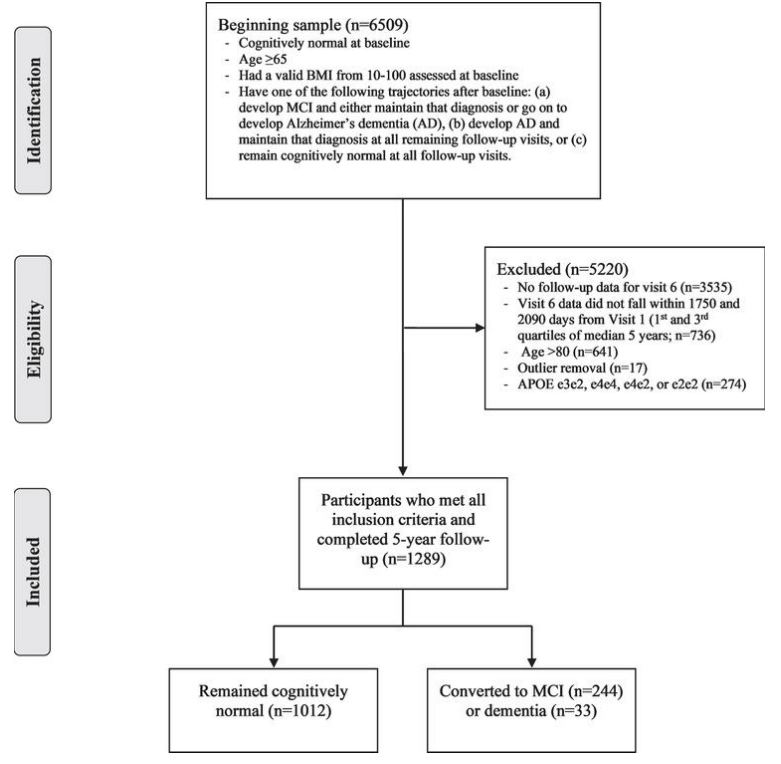


Table 1. Group Differences in BMI (Baseline and Five-year Change) and Demographics as a Function of APOE $\varepsilon 4$ Carrier Status and Conversion to MCl or Dementia

\begin{tabular}{|c|c|c|c|c|c|c|c|c|c|c|}
\hline & & & & & $\begin{array}{l}2 \times 2 \text { Factorial } \\
\text { ANOVA / } \\
\text { Pearson } \chi^{2}\end{array}$ & & & & & \\
\hline & $\varepsilon 4-$ & & $\varepsilon 4+$ & & Conversion & & APOE & & Interaction & \\
\hline Variable & Converters & Nonconverters & Converters & Nonconverters & $p$ & $E S$ & $p$ & $E S$ & $p$ & $E S$ \\
\hline $\mathrm{N}($ Total = 1289) & 159 & 744 & 118 & 268 & & & & & & \\
\hline Age, $\mathrm{M}(\mathrm{SD})$ & $74.3(4.0)$ & $72.0(4.5)$ & $73.1(4.3)$ & $70.8(4.2)$ & $<0.001$ & $-0.528^{a}$ & $<0.001$ & $0.269^{a}$ & 0.937 & $<0.001^{b}$ \\
\hline $\begin{array}{l}\text { Education, M } \\
\text { (SD) }\end{array}$ & $15.8(3.1)$ & $16.2(3.0)$ & $16.2(2.9)$ & $15.9(2.9)$ & 0.811 & $0.017^{a}$ & 0.636 & $0.033^{a}$ & 0.121 & $0.002^{b}$ \\
\hline Sex, N (\%Male) & 66 (41.5) & 246 (33.1) & $43(36.4)$ & $88(32.8)$ & 0.049 & $0.003^{c}$ & 0.832 & $<0.001^{c}$ & - & - \\
\hline $\begin{array}{l}\text { Race, N } \\
\text { (\%White) }\end{array}$ & $145(91.2)$ & $620(83.3)$ & $104(88.1)$ & $216(80.6)$ & 0.003 & $0.007^{c}$ & 0.413 & $<0.001^{\mathrm{c}}$ & - & - \\
\hline $\begin{array}{l}\text { Baseline BMI } \\
\left(\mathrm{kg} / \mathrm{m}^{2}\right), \mathrm{M}(\mathrm{SD})\end{array}$ & $26.6(4.9)$ & $27.3(5.2)$ & $26.8(4.9)$ & $27.1(5.0)$ & 0.335 & $0.069^{a}$ & 0.974 & $0.002^{\mathrm{a}}$ & 0.392 & $<0.001^{b}$ \\
\hline$\triangle \mathrm{BMI}, \mathrm{M}(\mathrm{SD})$ & $-0.03(1.0)$ & $0.007(1.0)$ & $-0.3(1.2)$ & $0.1(0.9)$ & 0.066 & $0.136^{a}$ & 0.168 & $0.101^{a}$ & $0.034^{d}$ & $0.004^{b}$ \\
\hline
\end{tabular}

$\triangle \mathrm{BMI}$, five-year age- and education-adjusted standardized residualized change (z-score units); Baseline BMI adjusted for age and education; ES, effect size: ${ }^{a}$ Cohen's $d$, ${ }^{b}$ partial eta ${ }^{2}$, and 'phi $^{2}$. ${ }^{\mathrm{d}}$ Follow-up Games-Howell analyses of simple effects showed the interaction was due to a greater decline in BMI for carriers who converted to $\mathrm{MCl} / \mathrm{AD}$ versus carriers who did not convert, $p=0.006, d=0.34$ rather than for noncarriers who converted versus noncarriers who did not convert, $p=0.65, d=0.02$. 


\section{Body mass index}

Baseline BMI ( $\left.{ }_{\mathrm{b}} \mathrm{BMI}\right)$ was calculated using first visit height $(\mathrm{m})$ and weight $(\mathrm{kg})$ and coded as a continuous measure $\left(\mathrm{kg} / \mathrm{m}^{2}\right)$. BMI at visit 6 , approximately five years from baseline, was also calculated as a continuous measure $\left(\mathrm{kg} / \mathrm{m}^{2}\right)$ from visit height $(\mathrm{m})$ and weight $(\mathrm{kg})$ at that timepoint.

\section{Statistical analysis}

Demographic information grouped by $A P O E \varepsilon 4$ status and conversion status is displayed in Table 1. Five-year change in $\mathrm{BMI}(\triangle \mathrm{BMI})$ was calculated using standardized residual change scores (z-score units; see Table 1 ).

Pearson $\chi^{2}$ tests were used to identify associations between conversion status and APOE $\varepsilon 4$ carrier status. Cochran-Mantel-Haenszel $(\mathrm{CMH})$ homogeneity tests were used to evaluate the possibility that sex or race (white versus nonwhite) may be confounders of this relationship. In addition, two-way factorial analyses of covariance (ANCOVA) investigated the main and interactive effects of conversion and APOE carrier status on age- and education-adjusted ${ }_{b} B M I$ and $\triangle B M I$. Any significant interaction was followed up with analysis of simple effects using Games-Howell post hoc comparisons due to unequal sample sizes and slight heterogeneity of variance across groups, whereby converters and nonconverters were compared separately for carrier and noncarrier groups. Last, a sequential logistic regression analysis was performed to assess prediction of conversion, first on the basis of ${ }_{\mathrm{b}} \mathrm{BMI}, A P O E \& 4$ status, and four demographic predictors and then after addition of the ${ }_{\mathrm{b}} \mathrm{BMI}$ $x A P O E$ interaction term. Demographic predictors were age, sex, education, and race. A second sequential logistic regression repeated the previously described model, replacing ${ }_{\mathrm{b}} \mathrm{BMI}$ with $\triangle \mathrm{BMI}$.

\section{RESULTS}

\section{Sample characteristics}

At approximately five years follow-up, substantially more carriers (30.6\%) converted to $\mathrm{MCl}$ or dementia than noncarriers (17.6\%), $\chi^{2}(1)=26.9, p<0.001$, Crude $O R=2.06$ (see Table 1). $\mathrm{CMH}$ tests of homogeneity suggested that neither race (nonwhite $O R=2.38$, white $O R=2.06$, $\mathrm{CMH}$ combined $O R=2.09, \chi^{2}(1)=0.11, p=0.738$ ) nor sex (male $O R=1.82$, female $O R=2.23, \mathrm{CMH}$ combined $O R=2.07, \chi^{2}(1)=0.48, p=0.488$ ) modified this association. Table 1 also shows that the proportion of males in each carrier group was comparable $(\varepsilon 4$ noncarriers: $n=312$ [34.6\%]; $\varepsilon 4$ carriers: $n=131$ [33.9\%]; $\varphi^{2}<0.001, p=0.83$ ), but there was a slightly larger proportion of men in the converter group (nonconverters: $n=334$ [33.0\%]; converters: $n=109$ [39.4\%]; $\varphi^{2}=0.003, p=0.049$ ). There were proportionally more white individuals ( $n=249[22.9 \%]$ ) in the converter group than nonwhites $\left.(n=28[13.7 \%]), \varphi^{2}=0.007, p=0.003\right)$. Carrier groups did not differ in their respective proportions of white individuals ( $\varepsilon 4$ noncarriers: $n=765$ [84.7\%]; $\varepsilon 4$ carriers: $n=320$ [82.9\%]; $\varphi^{2}<0.001, p=0.41$ ). Two-way factorial ANOVAs on age revealed main effects of conversion group and carrier status but no interaction effect, such that converters $(M=73.8$ years, $S D=4.2$ years) were significantly older on average than nonconverters ( $M=71.7$ years, $S D=4.5$ years) at baseline, and noncarriers $(M=72.4$ years, $S D=4.5$ years) were significantly older than carriers $(M=71.5$ years, $S D=4.4$ years). No main or interaction effects for conversion or carrier status were observed for number of years of education or for age- and education-adjusted ${ }_{b} B M I$.

When examining age- and education-adjusted $\triangle \mathrm{BMI}$, there were no main effects of conversion status, $F(1$, $1207)=3.38, p=0.066$, or carrier status, $F(1,1207)=1.91, p=0.168$. However, the interaction between conversion and carrier status on $\triangle \mathrm{BMI}$ was significant, $F(1,1207)=4.48, p=0.034$ (see Fig. 2 ). Games-Howell analyses of simple effects revealed that this interaction was driven by a significantly greater decline in BMI for carriers who converted to $\mathrm{MCl}$ or dementia $(M=-0.26, S D=1.2)$ than for carriers who did not convert $(M=0.10, S D=0.9), p=0.006, d=0.34$. There was no significant difference in $\triangle B M I$ between non-carriers who converted $(M=-0.03, S D=1.0)$ and who did not convert $(M=0.01, S D=1.0), p=0.646, d=0.018$. 
Fig. 2. Change in $\mathrm{BMI}$ as a Function of Conversion to $\mathrm{MCl}$ or Dementia (Top) and Both Conversion and APOE $\varepsilon 4$ Carrier Status (Bottom). Change in BMI represents the mean five-year standardized residualized change (z-score units) for each group. Numbers on $\mathrm{x}$-axes represent sample size within each group.
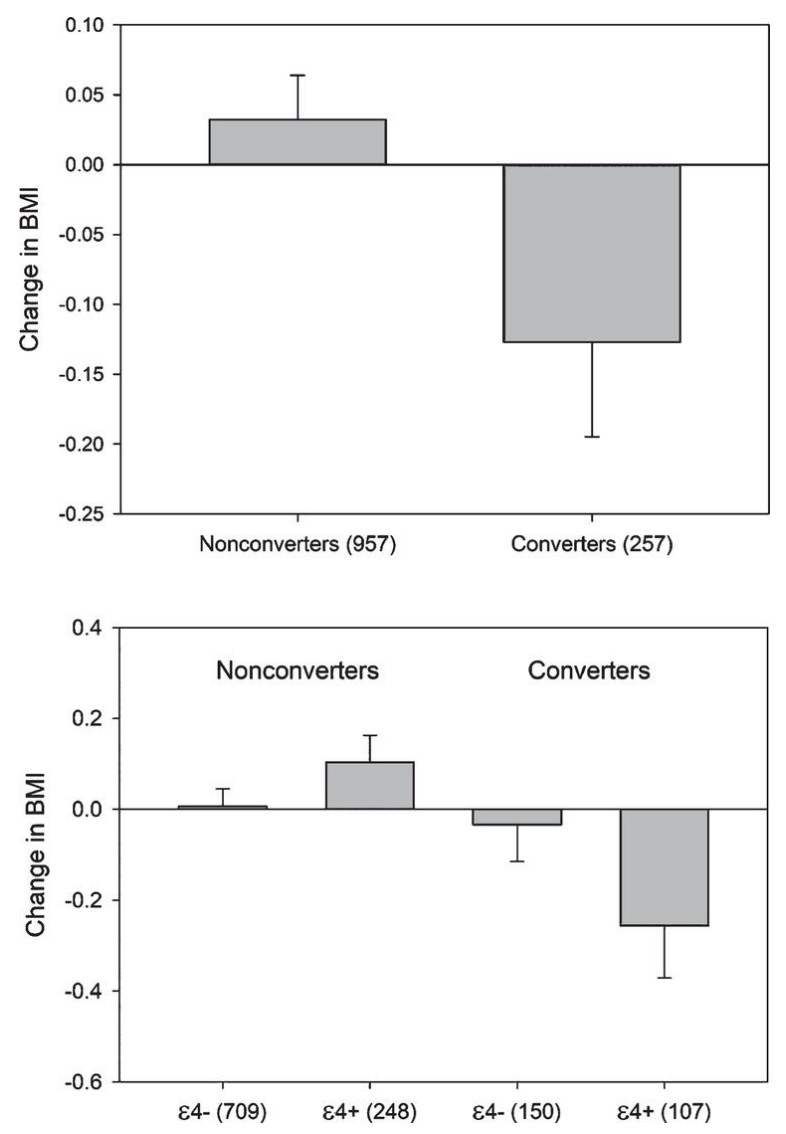

\section{APOE $\varepsilon 4$ and baseline BMI predicting conversion}

A sequential logistic regression analysis assessed whether carrier status, ${ }_{b} \mathrm{BMI}$, and their interaction predict conversion to $\mathrm{MCl}$ or dementia after controlling for age, sex, race, and education. Table 2 shows the results of a hierarchical binary logistic regression, where $A P O E \varepsilon 4$ status, $b \mathrm{BMI}$, age, sex, race, and education were entered simultaneously into the first model and the interaction between carrier status and ${ }_{\mathrm{b}} \mathrm{BMI}$ was added to the second model (only model 2 is displayed). As expected, $A P O E \varepsilon 4$ carrier status was a statistically significant predictor of conversion $(O R=2.43, S E=0.15, p<0.001)$, suggesting that the odds of conversion for $A P O E \varepsilon 4$ carriers was 2.4 times greater than for non-carriers. Race significantly predicted conversion as well $(O R=1.89, S E=0.23, p=0.006)$, indicating that the odds of conversion for white participants was 1.9 times greater than for nonwhite participants. Age was also a significant predictor ( $O R=1.13, S E=0.02, p<0.001)$, indicating that each one-year increase in age raised the odds of conversion by $13 \%$. ${ }_{b} \mathrm{BMI}$ did not significantly predict conversion status $(O R=0.99, S E=0.02, p=0.48)$, nor did sex $(O R=1.26, S E=0.15, p=0.12)$ or education $(O R=0.97, S E=0.03, p=0.22)$. The interaction between $A P O E \varepsilon 4$ carrier status and ${ }_{b} \mathrm{BMI}$, controlling for the previously entered demographic variables, was also non-significant in model $2(O R=1.02, S E=0.03, p=0.60)$. 
Table 2. Logistic Regression with APOE \&4 Carrier Status, Bmi (Baseline And Five-Year Change), Age, Sex, Education, and Race Predicting Conversion to $\mathrm{MCl}$ or Dementia

\begin{tabular}{|c|c|c|c|c|c|c|c|c|}
\hline Variable & $b$ & $S E$ & Wald & $d f$ & $p$ & OR & $\begin{array}{l}95 \% \mathrm{Cl} \text { for } \\
\text { OR }\end{array}$ & $\begin{array}{l}\text { Nagelkerke } \\
R^{2}\end{array}$ \\
\hline Model 1 - Baseline BMI („BMI) (Intercept) & -9.82 & 1.44 & 46.45 & 1 & $<0.001$ & $<0.001$ & & \\
\hline$A P O E$ & 0.89 & 0.15 & 35.93 & 1 & $<0.001$ & 2.44 & $1.82-3.26$ & \\
\hline Age & 0.12 & 0.02 & 51.40 & 1 & $<0.001$ & 1.12 & $1.09-1.16$ & \\
\hline Sex & 0.23 & 0.15 & 2.45 & 1 & 0.12 & 1.26 & $0.94-1.70$ & \\
\hline Education & -0.03 & 0.03 & 1.49 & 1 & 0.22 & 0.97 & $0.93-1.02$ & \\
\hline Race & 0.64 & 0.23 & 7.66 & 1 & 0.006 & 1.90 & $1.21-2.99$ & \\
\hline${ }_{b} \mathrm{BMI}$ & -0.02 & 0.02 & 0.83 & 1 & 0.36 & 0.98 & 0.95-1.02 & \\
\hline \multirow[t]{2}{*}{$A P O E^{*}{ }_{b} \mathrm{BMI}$} & 0.02 & 0.03 & 0.33 & 1 & 0.56 & 1.02 & $0.96-1.08$ & \\
\hline & & & & & & & & 0.112 \\
\hline $\begin{array}{l}\text { Model } 2 \text { - Five-Year Standardized Residual Change in BMI ( } \triangle \mathrm{BMI}) \\
\text { (Intercept) }\end{array}$ & -10.04 & 1.35 & 55.71 & 1 & $<0.001$ & $<0.001$ & & \\
\hline$A P O E$ & 0.85 & 0.16 & 29.25 & 1 & $<0.001$ & 2.33 & $1.72-3.17$ & \\
\hline Age & 0.11 & 0.02 & 42.12 & 1 & $<0.001$ & 1.12 & $1.08-1.16$ & \\
\hline Sex & 0.29 & 0.16 & 3.41 & 1 & 0.065 & 1.33 & $0.98-1.80$ & \\
\hline Education & -0.02 & 0.03 & 0.59 & 1 & 0.44 & 0.98 & $0.93-1.03$ & \\
\hline Race & 0.66 & 0.24 & 7.83 & 1 & 0.005 & 1.93 & $1.22-3.07$ & \\
\hline$\triangle \mathrm{BMI}$ & 0.01 & 0.09 & 0.01 & 1 & 0.92 & 1.01 & $0.84-1.21$ & \\
\hline \multirow[t]{2}{*}{$A P O E^{*} \triangle \mathrm{BMI}$} & -0.33 & 0.16 & 4.47 & 1 & 0.035 & 0.72 & $0.53-0.98$ & \\
\hline & & & & & & & & 0.113 \\
\hline
\end{tabular}

Sex: males =1, females =0; Race: white =1, nonwhite =0; $A P O E$ : carrier $=1$, noncarrier $=0$. 


\section{APOE $\varepsilon 4$ and change in BMI predicting conversion}

A second logistic regression analysis repeated the previous analysis with $\triangle \mathrm{BMI}$ replacing ${ }_{\mathrm{b}} \mathrm{BMI}$ in the model. Table 2 displays the results of the second hierarchical binary logistic regression, where APOE $\varepsilon 4$ status, $\triangle \mathrm{BMI}$, age, sex, race, and education were entered simultaneously into the first model and the interaction between carrier status and $\triangle \mathrm{BMI}$ was added to the second model (only model 2 is displayed). Again, APOE $\varepsilon 4$ status was a statistically significant predictor of conversion $(O R=2.40, S E=0.15, p<0.001)$, indicating that the odds of conversion to $\mathrm{MCl}$ or dementia are $140 \%$ greater for carriers than for noncarriers. Race remained a significant predictor of conversion as well $(O R=1.93, S E=0.24, p=0.005)$, signifying that being white (versus nonwhite) increased the odds of converting by $93 \%$. Age also remained a significant predictor $(O R=1.12, S E=0.02, p<0.001)$, indicating that a one-year increase in age raised the odds of conversion by $12 \% . \triangle \mathrm{BMI}$ did not significantly predict conversion $(O R=0.90, S E=0.07, p=0.14)$, nor did sex $(O R=1.33, S E=0.15, p=0.063)$ or education $(O R=0.98, S E=0.03, p=0.44)$. However, the interaction between $\triangle \mathrm{BMI}$ and carrier status was significant in the second model, $O R=0.72, S E=0.16, p=0.035$. To further interpret the interaction, an additional logistic regression assessed the effects of $\triangle \mathrm{BMI}$ on conversion separately for carriers and noncarriers, while controlling for age, sex, education, and race in the model. All predictors were entered simultaneously. $\triangle \mathrm{BMI}$ was a significant predictor of conversion for carriers only $(O R=0.73, S E=0.13, p=0.013)$, such that greater declines in BMI over the five-year period were associated with an increased likelihood of conversion. This relationship was not observed in noncarriers

$(O R=1.00, S E=0.094, p=0.98)$.

\section{DISCUSSION}

In our study, a decline in $\mathrm{BMI}$ over a five-year period, but not baseline $\mathrm{BMI}$, predicted conversion to $\mathrm{MCl}$ or dementia uniquely in $A P O E \& 4$ carriers. Thus, the results of our study suggest that risk of conversion to $\mathrm{MCl}$ or dementia may be greatest among $A P O E \varepsilon 4$ carriers who experience significant declines in BMI.

Weight loss has been associated with cognitive impairment and greater dementia risk across the age spectrum, but notably the investigation of the role of $A P O E$ as a potential moderator of this risk has been absent. One study examined the association of change in BMI and risk of $A D$ in 918 healthy older adults [21]. They found that losing one unit of BMI per year led to a $25 \%$ greater risk of AD compared to those with no change in BMI. Similarly, others have found that every one-unit decrease in BMI over a 26-year period from midlife to late-life was associated with a $20 \%$ greater risk of AD [22]. Additionally, a $>10 \%$ loss in BMI over a 3-year period has been associated with increased risk of dementia, whereas gains in BMI were not [39]. Other studies have found that both weight gain and loss are associated with greater risk of $A D$, with one recent study finding that rapid weight change characterized by greater than $10 \%$ loss or gain in BMI over two years increased risk of dementia by $20 \%$ compared to persons with a stable BMI [28]. For our study and others that did not find such an effect with weight gain, it is possible that the effect of weight loss on AD risk is simply greater and categorizing individuals into groups based on percent change in BMI with adequate sample sizes in each group is necessary to detect the smaller effect. Alternatively, it is possible that differential effects based on carrier status may be found if other studies had considered the role of the $A P O E \& 4$ allele, with obesity being protective in carriers yet harmful in noncarriers.

Past studies have demonstrated that obesity, especially in mid-life, is related to cognitive decline later in life [9, 14]. In our study, we did not find any effect of baseline BMI on conversion to $\mathrm{MCl}$ or dementia, and it was weight loss closer to the time of conversion rather than weight gain that predicted conversion. This discrepancy may be caused by weight loss masking the adverse effect of adiposity. Unintentional weight loss is common in old age, and typically signals the presence of pathologic processes that may contribute to the later development of $A D$ or other morbidities [21, 39, 40]. 
We also found a differential impact of $\triangle \mathrm{BMI}$ on $\mathrm{AD}$ risk based on carrier status, with the greatest effects of $\mathrm{BMI}$ change found in $A P O E \& 4$ carriers. Our finding that the relationship between $\mathrm{BMI}$ change and conversion to $\mathrm{MCl}$ or dementia is significant in $A P O E \varepsilon 4$ carriers but not noncarriers is consistent with past research that revealed a negative relationship between $\mathrm{BMI}$ and cognitive performance for carriers [31, 32]; however, these past studies did not examine conversion to $\mathrm{MCl}$ or dementia. Therefore, it appears that maintaining a healthy body weight is most important for those who are already genetically at risk for AD. For those studies that did not find a significant interaction between $\mathrm{BMI}$ and carrier status on risk of conversion [11, 33], several factors may be responsible for this difference. First, neither of these studies examined change in BMI over time as a predictor. Like these prior studies, the current research also found no relationship between BMI at baseline and carrier status on risk of conversion, suggesting that declines in BMI over time rather than BMI measures taken at a single timepoint are more predictive of conversion for carriers. Second, these studies measured BMI during midlife, whereas the present study examined BMI throughout late life, indicating that this relationship may be dependent on age. Finally, BMI was categorized into two [33] or three [11] groups in these previous studies which reduces power, whereas we examined $\mathrm{BMI}$ as a continuous predictor in the current study. For the one study that found the $A P O E \& 4$ allele did not moderate the relationship between weight loss over time and $A D$, this could be due to only men being included in the sample, as past research has found that the association between weight loss and the APOE \&4 allele was only present in women with dementia [41].

Not surprisingly, older age and the APOE \&4 allele were both significant predictors of conversion to $\mathrm{MCl}$ or dementia, which are two of the most well-established risk factors for $A D[42,43]$. More interesting, however, was our finding that race significantly predicted conversion, with white participants being nearly twice as likely to convert than their nonwhite counterparts. This finding is inconsistent with past research suggesting that older African Americans and Hispanics are significantly more likely than older whites to develop AD or other dementias [43,44]. However, white (versus nonwhite) race was associated with increased risk of conversion to $\mathrm{MCl}$ in other studies utilizing data from the NACC database, suggesting that this finding is unique to this particular sample [20]. To investigate the contribution of race further, the interaction between race and conversion to $\mathrm{MCl}$ or dementia on $\mathrm{BMI}$ (baseline and five-year change) and other demographic variables was examined. However, due to small sample sizes in the nonwhite, converter group leading to significant heterogeneity of variance, these results were not reported. Future research should examine this relationship in a larger group of minority individuals while also considering other factors that may account for significant changes in BMI. Lastly, education was not a significant predictor of conversion. While many studies have identified lower education as a risk factor for $\mathrm{MCl}$ or dementia [45-47], others have found no relationship [48, 49]. The association between education and dementia appears to be strongest for those with little to no education and could be influenced by diagnostic biases, whereby those with the lowest levels of education perform worse on cognitive tests of dementia despite no differences in functional impairment [49]. Our overall sample (mean age $=72.1$ ) had $16.1(S D=3.0)$ total mean years of education, which is much higher than the United States national average of 12.8 years for older adults aged 70-74 years according to 2010 data [50]. Thus, an effect of education may have been harder to detect due to the highly educated nature of this sample. Finally, a weak association between sex and conversion was found, whereby men were more likely to convert to $\mathrm{MCl}$ or dementia over the five-year observation period. It is unclear whether more men converted to $\mathrm{MCl}$ due to vascular reasons or due to frank AD. Although the literature has consistently identified higher incidence of dementia in women [51-53], sex differences typically do not emerge until after age 80 [54], and incident $\mathrm{MCl}$ has been shown to be higher in men than in women [55]. Our sample consisted primarily of converters to $\mathrm{MCl}$ and was restricted to participants aged 65 to 80 , thus explaining the observed sex differences.

The strengths of our study include the size of our overall sample and careful follow-up and characterization of the sample over five years. However, this study still has some limitations. First, the number of nonwhite individuals who converted was very low $(\mathrm{N}=28)$, limiting the interpretability of our results due to significant 
heterogeneity of variance. Larger samples are needed in order to obtain the power needed for a significant effect. As noted earlier, the normal healthy controls recruited by the ADRCs were more highly educated than the general population, thus limiting the generalizability of our findings. In addition, many of our significant findings were tempered by small effect sizes. We also did not have any data on the causes of weight loss/gain in our sample, and this information would be helpful to determine whether unintentional weight loss due to pathological aging was responsible for the greater declines in BMI for converters relative to nonconverters. Because change in $\mathrm{BMI}$ and conversion to $\mathrm{MCl}$ or dementia were observed across the same five-year timespan, it remains unknown whether a decline in $\mathrm{BMI}$ is a risk factor or an early pathological sign of $\mathrm{MCl} /$ dementia. Lastly, BMI has been criticized for being a crude measure of body composition, but studies have shown that it does correlate well with dual-energy X-ray absorptiometry (DEXA), which has been considered the gold standard measure of body composition [56-58]. Flegal et al. (2009) compared BMI with other anthropometric measures and DEXA in healthy older adults in the same age range as our sample. They found that BMI correlated highly with other anthropometric measures such as waist circumference (Men: $r=0.93$; Women: $r=0.88$ ) and waiststature ratio (Men: $r=0.93$; Women: $r=0.89$ ) and also had a reasonably strong correlation with DEXA (Men: $r=0.738$; Women: $r=0.763$ ) [56]. Thus, we feel justified in using BMI within this age group.

Nevertheless, our findings have some important implications for those at genetic risk for AD. This study demonstrated using a large, longitudinal cohort that experiencing a loss of BMI in old age increases one's risk of conversion for $A P O E \& 4$ carriers. The specificity of these relationships among $\varepsilon 4$ carriers suggest the possibility of concurrent changes in cognition and metabolism in those who convert to $\mathrm{MCl}$ or dementia. The precise mechanisms driving these associations are not fully understood but may reflect dysregulated brain lipid and glucose metabolism and reduced availability of fat from adipose tissue as a brain energy substrate during weight loss [36]. These effects may also be compounded by the combined impacts of decreased cellular cholesterol transport, increased neuro-inflammation, increased blood-brain barrier permeability, and amyloid-beta aggregation that are associated with the $A P O E \varepsilon 4$ allele [35]. Further research examining mechanisms that underly the relationships between $\mathrm{BMI}, A P O E \varepsilon 4$, and conversion to $\mathrm{MCl}$ or dementia could elucidate whether $\mathrm{BMI}$ is a causal factor or an indicator of conversion.

\section{ACKNOWLEDGMENTS}

The NACC database is funded by NIA/NIH Grant U01 AG016976 and NIA/NIH Grant U01 AG032984. NACC data are contributed by the NIA-funded ADCs: P30 AG019610 (PI Eric Reiman, MD), P30 AG013846 (PI Neil Kowall, MD), P50 AG008702 (PI Scott Small, MD), P50 AG025688 (PI Allan Levey, MD, PhD), P50 AG047266 (PI Todd Golde, MD, PhD), P30 AG010133 (PI Andrew Saykin, PsyD), P50 AG005146 (PI Marilyn Albert, PhD), P50 AG005134 (PI Bradley Hyman, MD, PhD), P50 AG016574 (PI Ronald Petersen, MD, PhD), P50 AG005138 (PI Mary Sano, PhD), P30 AG008051 (PI Thomas Wisniewski, MD), P30 AG013854 (PI M. Marsel Mesulam, MD), P30 AG008017 (PI Jeffrey Kaye, MD), P30 AG010161 (PI David Bennett, MD), P50 AG047366 (PI Victor Henderson, MD, MS), P30 AG010129 (PI Charles DeCarli, MD), P50 AG016573 (PI Frank LaFerla, PhD), P50 AG005131 (PI James Brewer, MD, PhD), P50 AG023501 (PI Bruce Miller, MD), P30 AG035982 (PI Russell Swerdlow, MD), P30 AG028383 (PI Linda Van Eldik, PhD), P30 AG053760 (PI Henry Paulson, MD, PhD), P30 AG010124 (PI John Trojanowski, MD, PhD), P50 AG005133 (PI Oscar Lopez, MD), P50 AG005142 (PI Helena Chui, MD), P30 AG012300 (PI Roger Rosenberg, MD), P30 AG049638 (PI Suzanne Craft, PhD), P50 AG005136 (PI Thomas Grabowski, MD), P50 AG033514 (PI Sanjay Asthana, MD, FRCP), P50 AG005681 (PI John Morris, MD), P50 AG047270 (PI Stephen Strittmatter, MD, PhD), and P30 AG053760 (PI Henry Paulson, MD). This project was also supported by R01AG022304 and P30AG062428 from the National Institute on Aging. The content is solely the responsibility of the authors and does not necessarily represent the official views of the National Institute on Aging or the National Institutes of Health. 
Authors' disclosures available online (https://www.j-alz.com/manuscript-disclosures/20-1360r1).

\section{REFERENCES}

[1] Michaelson DM (2014) $\varepsilon 4$ : The most prevalent yet understudied risk factor for Alzheimer's disease. Alzheimers Dement 10, 861-868.

[2] Holtzman DM , Herz J , Bu G (2012) Apolipoprotein E and apolipoprotein E receptors: Normal biology and roles in Alzheimer disease. Cold Spring Harb Perspect Med 2, a006312.

[3] Myers RH , Schaefer EJ , Wilson PWF , D’Agostino R , Ordovas JM , Espino A , Au R , White RF , Knoefel JE , Cobb JL, McNulty KA, Beiser A , Wolf PA (1996) Apolipoprotein E $\varepsilon 4$ association with dementia in a population-based study: The Framingham Study. Neurology 46, 673-677.

[4] Woodard JL, Sugarman MA , Nielson KA , Smith JC , Seidenberg M , Durgerian S, Butts A, Hantke N, Lancaster M , Matthews MA , Rao SM (2012) Lifestyle and genetic contributions to cognitive decline and hippocampal structure and function in healthy aging. Curr Alzheimer Res 9, 436-446.

[5] Krell-Roesch J , Feder NT , Roberts RO, Mielke MM , Christianson TJ , Knopman DS, Petersen RC, Geda YE (2018) Leisure-time physical activity and the risk of incident dementia: The Mayo Clinic Study of Aging. J Alzheimers Dis 63, 149-155.

[6] Podewils L , Guallar E , Kuller LH , Fried LP , Lopez OL , Carlson M , Lyketsos CG (2005) Physical activity, APOE genotype, and dementia risk: Findings from the Cardiovascular Health Cognition Study. Am J Epidemiol 161, 639-651.

[7] Rovio S, Kåreholt I , Helkala EL, Viitanen M , Winblad B , Tuomilehto J , Soininen H , Nissinen A , Kivipelto M (2005) Leisure-time physical activity at midlife and the risk of dementia and Alzheimer's disease. Lancet Neurol 4, 705-711.

[8] Chiang CJ, Yip PK, Wu SC, Lu CS, Liou CW , Liu HC, Liu CK, Chu CH, Hwang CS, Sung SF, Hsu YD, Chen CC , Liu SI , Yan SH , Fong CS , Chang SF, You SL, Chen CJ (2007) Midlife risk factors for subtypes of dementia: A nested case-control study in Taiwan. Am J Geriatr Psychiatry 15, 762771.

[9] Dahl AK, Hassing LB , Fransson EI , Gatz M , Reynolds CA , Pedersen NL (2013) Body mass index across midlife and cognitive change in late life. Int J Obes 37, 296-302.

[10] Fitzpatrick AL , Kuller LH , Lopez OL , Diehr P , O’Meara ES , Longstreth WT , Luchsinger JA (2009) Midlife and late-life obesity and the risk of dementia: Cardiovascular health study. Arch Neurol 66, 336-342.

[11] Kivipelto M , Ngandu T , Fratiglioni L, Viitanen M , Kåreholt I , Winblad B , Helkala EL , Tuomilehto J , Soininen $\mathrm{H}$, Nissinen A (2005) Obesity and vascular risk factors at midlife and the risk of dementia and Alzheimer disease. Arch Neurol 62, 1556-1560.

[12] Whitmer RA , Gustafson DR , Barrett-Connor E , Haan MN , Gunderson DEP, Yaffe K (2008) Central obesity and increased risk of dementia more than three decades later. Neurology 71, 1057-1064.

[13] Whitmer RA , Gunderson EP , Barrett-Connor E, Quesenberry CP , Yaffe K (2005) Obesity in middle age and future risk of dementia: A 27 year longitudinal population based study. Br Med J 330, 13601362.

[14] Xu WL , Atti AR , Gatz M , Pedersen NL , Johansson B , Fratiglioni L (2011) Midlife overweight and obesity increase late-life dementia risk: A population-based twin study. Neurology 76, 1568-1574.

[15] Ma Y , Ajnakina O , Steptoe A , Cadar D (2020) Higher risk of dementia in English older individuals who are overweight or obese. Int J Epidemiol 49, 1353-1365.

[16] Chuang YF , An Y, Bilgel M , Wong DF , Troncoso JC , O’Brien RJ , Breitner JC, Ferruci L, Resnick SM , Thambisetty M (2016) Midlife adiposity predicts earlier onset of Alzheimer's dementia, neuropathology and presymptomatic cerebral amyloid accumulation. Mol Psychiatry 21, 910-915.

[17] Rajan KB , Skarupski KA , Rasmussen HE , Evans DA (2014) Gene-environment interaction of body mass index and apolipoprotein E $\varepsilon 4$ allele on cognitive decline. Alzheimer Dis Assoc Disord 28, 134-140. 
[18] Doruk H , Naharci MI , Bozoglu E , Isik AT , Kilic S (2010) The relationship between body mass index and incidental mild cognitive impairment, Alzheimer's disease, and vascular dementia in elderly. J Nutr Health Aging 14, 834-838.

[19] Hughes TF , Borenstein AR, Schofield E , Wu Y, Larson EB (2009) Association between late-life body mass index and dementia: The Kame Project. Neurology 72, 1741-1746.

[20] Bell SP, Liu D, Samuels LR, Shah AS, Gifford KA, Hohman TJ , Jefferson AL (2017) Late-life body mass index, rapid weight loss, apolipoprotein $\mathrm{E} \varepsilon 4$ and the risk of cognitive decline and incident dementia. J Nutr Health Aging 21, 1259-1267.

[21] Buchman AS, Wilson RS, Bienias JL, Shah RC, Evans DA, Bennett DA (2005) Change in body mass index and risk of incident Alzheimer disease. Neurology 65, 892-897.

[22] Tolppanen AM , Ngandu T , Kåreholt I , Laatikainen T , Rusanen M , Soininen H , Kivipelto M (2014) Midlife and late-life body mass index and late-life dementia: Results from a prospective population-based cohort. J Alzheimers Dis 38, 201-209.

[23] Sobów T, Fendler W , Magierski R (2014) Body mass index and mild cognitive impairment-to-dementia progression in 24 months: A prospective study. Eur J Clin Nutr 68, 1216-1219.

[24] Shim SM , Song J, Kim JH , Jeon JP (2016) Conversion pattern and predictive factor of mild cognitive impairment in elderly Koreans. Arch Gerontol Geriatr 64, 146-150.

[25] Cova I, Clerici F , Rossi A , Cucumo V , Ghiretti R, Maggiore L, Pomati S, Galimberti D , Scarpini E , Mariani C , Caracciolo B (2016) Weight loss predicts progression of mild cognitive impairment to Alzheimer's disease. PLoS One 11, e0151710.

[26] Ogunniyi A , Gao S , Unverzagt FW , Baiyewu O , Gureje O , Nguyen JT , Smith-Gamble V , Murrell JR , Hake AM , Hall KS , Hendrie HC (2011) Weight loss and incident dementia in elderly Yoruba Nigerians: A 10-year follow-up study. Int Psychogeriatr 23, 387-394.

[27] Alhurani RE, Vassilaki M , Aakre JA, Mielke MM , Kremers WK, Machulda MM , Geda YE , Knopman DS , Peterson RC, Roberts RO (2016) Decline in weight and incident mild cognitive impairment: Mayo Clinic Study of Aging. JAMA Neurol 73, 439-446.

[28] Park S , Jeon SM , Jung SY , Hwang J , Kwon JW (2019) Effect of late-life weight change on dementia incidence: A 10-year cohort study using claim data in Korea. BMJ Open 9, e021739.

[29] Emmerzaal TL, Kiliaan AJ , Gustafson DR (2015) 2003-2013: A decade of body mass index, Alzheimer's disease, and dementia. J Alzheimers Dis 43, 739-755.

[30] Ghebranious N, Mukesh B, Giampietro PF , Glurich I, Mickel SF , Waring SC , McCarty CA (2011) A pilot study of gene/gene and gene/environment interactions in Alzheimer disease. Clin Med Res 9, 1725.

[31] Sachs-Ericsson NJ , Sawyer KA , Corsentino EA , Collins NA, Blazer DG (2010) APOE $\varepsilon 4$ allele carriers: Biological, psychological, and social variables associated with cognitive impairment. Aging Ment Health 14, 679-691.

[32] Blautzik J , Kotz S , Brendel M , Sauerbeck J , Vettermann F , Winter Y , Bartenstein P , Ishii K, Rominger A (2018) Relationship between body mass index, APOE4 status, and PET-based amyloid and neurodegeneration markers in amyloid-positive subjects with normal cognition or mild cognitive impairment. J Alzheimers Dis 65, 781-791.

[33] Hassing LB , Dahl AK, Thorvaldsson V , Berg S, Gatz M , Pedersen NL , Johansson B (2009) Overweight in midlife and risk of dementia: A 40-year follow-up study. Int J Obes 33, 893-898.

[34] Stewart R, Masaki K , Xue QL , Peila R, Petrovitch H , White LR , Launer LJ (2005) A 32-year prospective study of change in body weight and incident dementia: The Honolulu-Asia Aging Study. Arch Neurol 62, 55-60.

[35] Yassine HN , Finch CE (2020) APOE alleles and diet in brain aging and Alzheimer's disease. Front Aging Neurosci 12, 150.

[36] Yassine HN , Anderson A, Brinton R, Carmichael O , Espeland MA , Hoscheidt S, Hugenschmidt CE , Keller JN , Peters A , Pi-Sunyer X (2020) Do menopausal status and APOE4 genotype alter the long- 
term effects of intensive lifestyle intervention on cognitive function in women with type 2 diabetes mellitus? Neurobiol Aging 92, 61-72.

Beekly DL , Ramos EM , Lee WW , Deitrich WD , Jacka ME , Wu J , Hubbard JL , Koepsell TD , Morris JC, Kukull WA (2007) The National Alzheimer's Coordinating Center (NACC) Database: The Uniform Data Set. Alzheimer Dis Assoc Disord 21, 249-258.

[38] Besser L, Kukull W , Knopman DS, Chui H, Galasko D , Weintraub S , Jicha G , Carlsson C , Burns J , Quinn J , Sweet RA, Rascovsky K, Teylan M , Beekly D , Thomas G , Bollenbeck M , Monsell S, Mock C , Hua Zhou X, Thomas N , Robichaud E , Dean M , Hubbard J , Jacka M , Schwabe-Fry K, Wu J (2018) Version 3 of the National Alzheimer's Coordinating Center's Uniform Data Set. Alzheimer Dis Assoc Disord 32, 351-358.

[39] Atti AR , Palmer K, Volpato S, Winblad B , De Ronchi D , Fratiglioni L (2008) Late-life body mass index and dementia incidence: Nine-year follow-up data from the Kungsholmen Project. J Am Geriatr Soc 56, 111-116.

[40] Nilsson PM (2008) Is weight loss beneficial for reduction of morbidity and mortality? What is the controversy about?. Diabetes Care 31(Suppl 2), S278-S283.

[41] Vanhanen M , Kivipelto M , Koivisto K , Kuusisto J, Mykkänen L, Helkala EL , Hänninen T , Kervinen K, Kesäniemi YA , Laakso MP, Soininen H , Laakso M (2001) APOE- $\varepsilon 4$ is associated with weight loss in women with AD: A population-based study. Neurology 56, 655-659.

[42] Armstrong RA (2019) Risk factors for Alzheimer's disease. Folia Neuropathol 57, 87-105.

[43] Alzheimer's Association (2019) 2019 Alzheimer's disease facts and figures. Alzheimers Dement 15, 321-387.

[44] Mehta KM , Yeo GW (2017) Systematic review of dementia prevalence and incidence in United States race/ethnic populations. Alzheimers Dement 13, 72-83.

[45] Tervo S, Kivipelto M , Hänninen T, Vanhanen M, Hallikainen M , Mannermaa A, Soininen H (2004) Incidence and risk factors for mild cognitive impairment: A population-based three-year follow-up study of cognitively healthy elderly subjects. Dement Geriatr Cogn Disord 17, 196-203.

[46] Contador I, del Ser T , Llamas S, Villarejo A , Benito-León J , Bermejo-Pareja F (2017) Impact of literacy and years of education on the diagnosis of dementia: A population-based study. J Clin Exp Neuropsychol 39, 112-119.

[47] Roe CM , Xiong C , Miller JP , Morris JC (2007) Education and Alzheimer disease without dementia: Support for the cognitive reserve hypothesis. Neurology 68, 223-228.

[48] Nitrini R, Caramelli P, Herrera E , Bahia VS , Caixeta LF , Radanovic M , Anghinah R , Charchat-Fichman H , Porto CS , Carthery MT , Hartmann APJ , Huang N , Smid J , Lima EP , Takada LT , Takahashi DY (2004) Incidence of dementia in a community-dwelling Brazilian population. Alzheimer Dis Assoc Disord 18, 241-246.

[49] Sharp ES , Gatz M (2011) Relationship between education and dementia: An updated systematic review. Alzheimer Dis Assoc Disord 25, 289-304.

[50] Barro R, Lee J-W (2013) A new data set of educational attainment in the world, 1950-2010. J Dev Econ 104, 184-198.

[51] Brayne C, Gill C , Huppert FA , Barkley C , Gehlhaar E , Girling DM , O’Connor DW , Paykel ES (1995) Incidence of clinically diagnosed subtypes of dementia in an elderly population: Cambridge project for later life. Br J Psychiatry 167, 255-262.

[52] Seshadri S, Wolf PA, Beiser A , Au R, McNulty K, White R, D'Agostino RB (1997) Lifetime risk of dementia and Alzheimer's disease: The impact of mortality on risk estimates in the Framingham Study. Neurology 49, 1498-1504.

[53] Ott A, Breteler MMB , Van Harskamp F , Stijnen T, Hofman A (1998) Incidence and risk of dementia: The Rotterdam Study. Am J Epidemiol 147, 574-580.

[54] Beam CR , Kaneshiro C, Jang JY, Reynolds CA , Pedersen NL , Gatz M (2018) Differences between women and men in incidence rates of dementia and Alzheimer's disease. J Alzheimers Dis 64, 1077-1083. 
[55] Roberts RO , Geda YE , Knopman DS , Cha RH , Pankratz VS , Boeve BF , Tangalos EG , Ivnik RJ , Rocca WA , Petersen RC (2012) The incidence of $\mathrm{MCl}$ differs by subtype and is higher in men: The Mayo Clinic Study of Aging. Neurology 78, 342-351.

[56] Flegal KM , Shepherd JA, Looker AC , Graubard BI, Borrud LG , Ogden CL , Harris TB , Everhart JE , Schenker N (2009) Comparisons of percentage body fat, body mass index, waist circumference, and waist-stature ratio in adults. Am J Clin Nutr 89, 500-508.

[57] Akindele MO, Phillips JS, Igumbor EU (2016) The relationship between body fat percentage and body mass index in overweight and obese individuals in an urban African setting. J Public Health Africa 7, 15-19.

[58] Grier T, Canham-Chervak M , Sharp M , Jones BH (2015) Does body mass index misclassify physically active young men. Prev Med Rep 2, 483-487. 